\title{
ELECTROLYTIC IODINATION OF FASCIOLA HEPATICA ANTIGEN WITH ${ }^{125 I}$
}

\author{
J. TOMÁNEK, J. HAMPL and M. SEDLÁCEKK \\ Veterinary Research Institute, 62132 Brno
}

Received July 28, 1980

\begin{abstract}
Tománek J., J. Hampl, M. Sedláček: Electrolytic Iodination of Fasciola hepatica Antigen with ${ }^{125} I$. Acta vet. Brno, 50, 1981: $101-103$.

The protein-bound radioiodine percentage and the stability and specificity of the protein fraction of Fasciola hepatica antigen labelled with ${ }^{125} \mathrm{I}$ by electrolytic iodination were compared with the data obtained for the same batch of the antigenic fraction labelled by the oxidation procedure using chloramine $T$. There were no significant differences between the results obtained with the two methods.

Diagnosis of fascioliasis, oxidation method of iodination, protein-bound radioiodine percentage, stability, iodinated antigen.
\end{abstract}

Antibodies, antigens and other proteins used in radioimmunological studies have generally been labelled with ${ }^{125}$ I because of its convenient half-life, radiochemical purity and detection efficiency. The protein iodination itself occurs after the radioactive iodide has been brought into the reactive form by means of an oxidizing agent. Since this agent should not affect the functional groups of the iodinated protein in an undesired way, efforts have been made to replace chemical methods of oxidation by milder electrolytic and enzymic procedures.

In a previous study (Tománek et al. 1981) we investigated the possibility of labelling Fasciola hepatica antigen by the oxidation method using chloramine $T$. The present study was designed to test the possibility of labelling this antigenic fraction electrolytically according to $\mathrm{Katz}$ and Bonorris (1968) and to compare the results with those obtained by the previous method.

\section{Materials and Methods}

The protein fraction of $F$. hepatica antigen was prepared as described previously (Tománek et al. 1981) and was labelled with $\mathrm{Na}^{125}$ I electrolytically according to $\mathrm{Katz}$ and Bonorris (1968) in a platinum crucible of $9 \mathrm{sq} . \mathrm{cm}$ surface area using of current of $50 \mu \mathrm{A} / \mathrm{sq} . \mathrm{cm}$. A portion of the same batch of this antigenic fraction was labelled by the oxidation method with chloramine $\mathrm{T}$ according to McConahey and Dix on (1966) for comparison. In both methods, the unreacted radioactive iodide was removed by dialysis against buffered saline, $\mathrm{pH} 7.2$, and distilled water. Checks upon the completeness of its removal were carried out by ascending paper. chromatography according to Schmidt et al. (1974) and the results were evaluated by measurement in an Actigraph III, Nuclear Chicago.

The percentage of protein-bound radioiodine was computed from the total ${ }^{125}$ I activity in the reaction mixture and the activity recorded after unreacted radioactive iodide was separated from the labelled antigen by dialysis.

The stability of iodinated antigens stored at $+4{ }^{\circ} \mathrm{C}$ was evaluated by ascending paper chromatography using an Actigraph III, Nuclear Chicago.

The antigenic specificity of iodinated antigens was checked by direct radioimmunodiffusion with positive sera from $F$. hepatica-infected animals and with negative control sera. 


\section{Results}

The protein-bound radioiodine percentage of $F$. hepatica antigen was 24.2 to 27.8 per cent with the electrolytic procedure and 23.3 per cent with the oxidation method using chloramine $T$. The yield of electrolytic iodination as a function

per cent

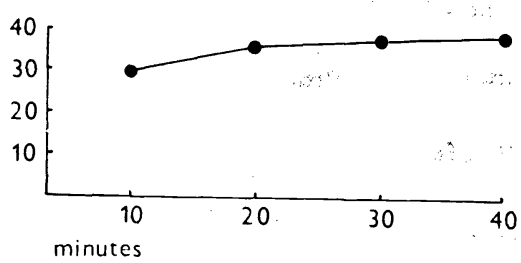

- Fig. 1.

The yield of electrolytic iodination of the protein fraction of Fasciola hepatica antigen as a function of time of time is presented in Fig. 1. Practically no further increase was achieved when the reaction was prolonged beyond 20 minutes.

The stability of antigens iodinated by the two procedures was satisfactory. They were stable up to 30 days. At 38 and 62 days the proportions of unreacted radiactive iodide were 2 and 4 per cent, respectively, with the electrolytic procedure and 5 and 6 per cent with the oxidation procedure.

Direct radioimmunodiffusion with positive sera from $F$. hepatica-infected animals and with control negative sera showed the specificity and properties of $F$. hepatica antigens iodinated by the two procedures was practically the same. The pattern of immunodiffusion of the labelled antigens in agar gel against serum antibodies was the same as in unlabelled antigen.

\section{Discussion}

The protein-bound radioiodine percentage of the antigenic fractions of $F$. hepatica iodinated by the two procedures was practically the same. It was affected in general by the quality of the antigen and by that of the $\mathrm{Na}^{125} \mathrm{I}$ employed. Both iodination methods have been claimed to be very suitable particularly for the labelling of proteins. The reaction conditions have been chosen so that the damage to protein molecules may be minimal. Viewed in this light the electrolytic procedure is superior to the oxidation one because no further components are added to the reaction mixture that might cause denaturation of the iodinated protein. However, for practical use of the iodinated antigen in some radioimmunological reactions the oxidation procedure with chloramine $\mathrm{T}$ seems more convenient because it does not require a special laboratory equipment. With regard to the stability of ${ }^{125}$ I-labelled antigen, the differences between the two iodination procedures are negligible.

\section{Jodace antigenu z Fasciola hepatica ${ }^{125} \mathrm{~J}$ elektrolytickou metodou}

$\mathrm{U}$ bílkovinné frakce antigenu $\mathrm{z}$ motolic Fasciola hepatica značené ${ }^{125} \mathrm{~J}$ elektrolytickou metodou byla srovnávána účinnost značení, stabilita a specifičnost se stejnou šarží antigenní frakce značené oxidační metodou s chloraminem $T$. Výsledky dosažené oběma metodami se významně nelišily. 


\section{Ииодирование антигена из Fasciola hepatica ${ }^{125} \mathrm{~J}$ электролитическим методом}

$\mathrm{y}$ белковой фракции антигена из двуусток Fasciola hepatica, меченной ${ }^{125} \mathrm{~J}$, әлектролитическим методом сравнивались эффективность получения меченного соединения, стабильность и специфичность с одинаковой партией антигенной фракции, меченной окислительным методом с хлорамином Т. Достигнутые с помощью обоих методов результаты существенным образом не отличались.

\section{References}

McCONAHEY, P. J. - DIXON, F. J.: A method of trace iodination of proteins for immunologic studies. Int. Arch. Allergy, 29, 1966: 185-189.

KATZ, J. - BONORRIS, G.: Electrolytic iodination of proteins with $\mathrm{I}^{125}$ an $\mathrm{I}^{131}$. J. Lab. clin. Med., 72, 1968, 6: 966-970.

LOWRY, O. H. - ROSENBROUGH, N. J. - FARR, A. L. - RANDAL, R. J.: Protein measurement with the Folin phenol reagent. J. Biol. Chem., 193, 1951: 265-275.

SCHMIDT, H. E. - TEICHMANN, B. - VOGT, R. - HERZMANN, H.: ${ }^{\prime 131} \mathrm{~J}-$ Markierung von Antikörpern nach der Chloramin T-Metode. Modellexperimente mit Kaninchen-Gammaglobulin und Anti-Pferdeserumalbumin-Antikörpern. Isotopenpraxis, 10, 1974: 401-407.

TOMÁNEK, J. - HAMPL, J. - SEDLÁČEK, M. - WILLOMITZER, J. - CHROUSTOVÁ, E.: Labelling of protein fractions of Fasciola hepatica antigen with ${ }^{125}$ I. Acta vet. Brno, 50, 1981: $97-100$. 